\title{
PKM SOPIR GOJEK ONLINE MANADO
}

\author{
Fivy Aprylianne Andries \\ Universitas Negeri Manado
}

\begin{abstract}
ABSTRAK
Sebagai kota terbesar di wilayah ini, Manado merupakan tempat pariwisata yang penting bagi pengunjung. Ekowisata merupakan atraksi terbesar Manado. Selain memiliki objek-objek wisata yang menarik, salah satu keunggulan pariwisata kota Manado adalah letaknya yang strategis ke objek-objek wisata di hinterland, khususnya di Minahasa yang dapat dijangkau dalam waktu 1 s/d 3 jam dari kota Manado.

Pariwisata merupakan salah satu sektor pembangunan yang saat ini sedang digalakkan oleh pemerintah. Kota Manado memiliki berbagai potensi pariwisata diantaranya objek wisata alam dan objek wisata budaya serta beragam atraksi. Wisatawan asing yang berkunjung ke Manado adalah tamu yang harus dilayani dengan baik. Untuk itu masyarakat harus dapat berkomunikasi dengan menggunakan Bahasa Inggris dengan para wisatawan, agar wisatawan merasa senang di Manado. Namun masih sopir Gojek Online, yang tidak dapat mampu bahasa Inggris, padahal mereka yang bersentuhan langsung dengan para wisatawan asing, yang mereka lakukan ketika melayani dengan wisman hanya menggunakan bahasa tubuh atau menggunakan penerjemah. Untuk itu perlu diadakan pelatihan untuk meningkatkan kemampuan berbahasa Inggris, baik dari: Speaking, listening, reading, writing dan vocabulary bagi sopir Gojek Online agar dapat mereka melayani dengan jasa kendaraan mereka serta memperkenalkan dan mempromosikan potensi wisata Kota Manado beserta industri pendukungnya, dan meningkatkan kesejahteraan masyarakat. Metode yang digunakan dalam pelatihan ini adalah Metode ceramah, Metode Diskusi dan Simulasi dan Metode pendampingan Kegiatan pelatihan bagi sopir Gojek Online akan dilaksanakan selama 3 bulan,.. Materi Bahasa Inggris yang berikan: berbagai conversation, vocabulary, reading text, alat tulis dan buku. Materi yang diberikan meliputi: Introduction, Greeting, Dealing with numbers (addres, time, date), Giving direction, Asking for information, Cross culture understanding .
\end{abstract}




\section{PENDAHULUAN}

Kota Manado adalah ibu kota dari provinsi Sulawesi Utara. Kota Manado sering kali disebut sebagai Manado. Manado terletak di Teluk Manado, dan dikelilingi oleh daerah pegunungan. Kota ini memiliki 408.354 penduduk pada Sensus 2010, menjadikannya kota terbesar kedua di Sulawesi setelah Makassar.

Sebagai kota terbesar di wilayah ini, Manado merupakan tempat pariwisata yang penting bagi pengunjung. Ekowisata merupakan atraksi terbesar Manado. Selain memiliki objekobjek wisata yang menarik, salah satu keunggulan pariwisata kota Manado adalah letaknya yang strategis ke objek-objek wisata di hinterland, khususnya di Minahasa yang dapat dijangkau dalam waktu $1 \mathrm{~s} / \mathrm{d} 3$ jam dari kota Manado. Objekobjek wisata tersebut antara lain, Vulcano Area di Tomohon, Desa Agrowisata Rurukan-Tomohon, Panorama pegunungan dan Danau Tondano, Batu Pinabetengan dan Taman Purbakala Waruga Sawangan Kecamatan Airmadidi Kab. Minahasa Utara.

Seperti diketahui, jumlah wisatawan dalam dan luar Indonesia yang datang berkunjung ke Manado semakin meningkat. Mulai tibanya mereka di bandara Sam Ratulangi mereka membutuhkan transportasi untuk mencari dan mengantar ke tempat penginapan, bahkan selanjutnya pergi ke tempat yang menjadi tujuan wisatanya. Sistem transportasi darat Kota Manado dilayani oleh minibus angkutan kota yang biasa disebut mikrolet, taksi argo dan Bus DAMRI, tetapi bus yang beroperasi di dalam kota sudah tidak ada. Sebagian besar rute dalam kota dilayani oleh mikrolet yang menghubungkan beberapa terminal bus dalam maupun luar kota dengan pusat kota Manado. Mikrolet umumnya beroperasi hingga pukul 22.00 Wita (hari kerja) atau pukul 00.00 Wita (akhir pekan). Menaiki transportasi umumnya mikrolet di manado ada yang unik, umumnya Mikrolet di Manado sudah di modifikasi dan dilengkapi dengan sound system, ada juga yang menaruh layar LCD bahkan ada juga yang memodifikasi bagian interior mobil, ini untuk memenuhi tingkat kenyamanan penumpang dan taksi umumnya melayani rute-rute ke luar kota sedangkan Bus DAMRI melayani rute Bandara Terminal Bus luar kota di Malalayang. Yang paling terbaru Manado telah memiliki transportasi Online yang membuat kemudahan yang sangat luar biasa bagi penduduk, yang beroperasi 1 x24 jam, yaitu GOJEK, GRAB \& UBER.

Ada banyak wisatawan asing yang datang ke Manado yang melihat keadaan jalan di Manado yang sangat macet. Oleh karena itu mereka tidak ingin menggunakan transportasi berupa mobil, tetapi mereka lebih memilih alat transportasi yang menggunakan sepeda motor, khususnya Gojek Online. Ketika wisatawan asing tiba di Indonesia, ia akan mudah memesan transportasi dari aplikasi mereka. Hal ini tidak akan berbeda jauh tatkala menggunakannya di negara asal mereka.

Gojek merupakan salah satu bentuk transportasi umum di Indonesia berupa sepeda motor atau sepeda yang disewakan dengan cara memboncengkan penumpang. Penumpang biasanya satu orang namun kadang bisa berdua, sang sopir akan mengantar ke tujuan yang diinginkan penumpangnya. Gojek banyak digunakan oleh penduduk kota-kota besar seperti di Manado, karena kelebihannya dengan angkutan lain. Gojek adalah sebuah layanan booking ojek melalui aplikasi Gojek yang bisa didownload di Smartphone android \& iPhone. Pendiri Gojek adalah putera asli Indonesia lulusan Harvard, Nadiem Makarim. Banyak orang suka menggunakan Gojek karena lebih cepat dan dapat melewati sela-sela kemacetan di kota. Selain itu dapat menjangkau daerah-daerah dengan ganggang yang sempit dan sulit dilalui oleh mobil.

Gojek menawarkan 4 (empat) jasa layanan yang bisa dimanfaatkan oleh para pelanggannya: Instant Courier (Pengantaran Barang), Transport (Jasa Angkutan), Shopping (Belanja) dan Corporate (Kerjasama dengan perusahaan untuk jasa kurir) yang menekankan keunggulan dalam Kecepatan, Inovasi dan Interaksi Sosial. Kenapa GO-JEK warnanya hijau? Hijau adalah warna yang menyimbolkan pertumbuhan dan kebangkitan. Hijau menandakan stabilitas dan ketahanan; tetapi juga diartikan sebagai kemakmuran dan sesuatu yang berlimpah. Hijau adalah warna yang memiliki kombinasi arti positif, seperti halnya GO-JEK yang mempunyai misi untuk membawa pengaruh positif bagi lingkungan sekitarnya.

Di era modern seperti saat ini, kita diharuskan untuk menguasai penggunaan bahasa Inggris. Bagaimana tidak, salah satu persyaratan untuk melamar pekerjaan pun diharuskan bisa berbahasa Inggris. Dengan kemampuan berbahasa dapatlah meningkatkan kesejahteraan para mitra melalui berbagai program manfaat. Kemampuan bahasa Inggris sangat dibutuhkan bagi para driver -Ojek karena dapat membantu para mitra driver dalam memberikan pelayanan terbaik kepada pelanggan, apalagi beberapa pelanggan mereka adalah ekspatriat. Jadi Kemampuan berbahasa Inggris diperlukan supaya para mitra lebih kompeten dan bisa berkomunikasi dengan baik saat menjalankan order. Dengan adanya pelayanan tukang ojek pariwisata atau TOP, dengan demikian 
akan memudahkan pelayanan transportasi bagi wisatawan yang hendak berlibur ke Manado.

Kemampuan komunikasi bagi seorang Gojek Online menurut kami adalah hal yang penting. Mengapa bisa begitu? Hendaklah seorang sopir ojek harus mampu berbicara dengan tamu agar tamu merasa nyaman. Selain untuk kenyamanan tamu, komunikasi yang bagus juga diperlukan agar sopir mampu menjelaskan berbagai hal yang ada di sekitar tempat yang dituju dengan baik. Semisal ada orang asing yang datang ke Manado dan ingin jalan-jalan melihat keadaan kota Manado. Gojek Online pun ingin menyambut turis itu sejak dari bandara. Adalah baik jika seorang sopir Gojek Online ketika tamu asing menggunakan jasanya ia hendaknya mampu berkomunikasi dengan baik bahkan lebih dari itu dapat menceritakan sekilas mengenai tempattempat yang ia kunjungi sebagai gambaran awal untuk tamu. Namun kenyataan ada banyak sopir Gojek Online yang ketika mengantar tamu asing mereka selama perjalanan tidak pernah berbicara. Mereka hanya mengantar sampai ditempat tujuan itu mereka pikir sudah cukup. Pengendara yang demikian tidak dapat meningkatkan mendapatkannya.

Saat ini pemerintah kota Manado menyelenggarakan event yang berskala nasional dan internasional dan kota ini semakin ramai dikunjungi oleh turis domestik, objek-objek wisata pun tak luput dari turis manca negara. Banyak wisatawan asing biasanya mereka memanfaatkan jasa Gojek Online untuk menemani perjalanan berwisata mereka. Di sinilah pentingnya kemampuan berbahasa Inggris bagi para sopir Gojek Online. Dengan bahasa Inggris, para sopir akan dapat berkomunikasi dengan para turis asing dari luar negeri. Sehingga potensi salah paham antara sopir Gojek Online dan wisatawan asing tidak terjadi dan pendapatan para sopir rental pun bertambah. Oleh karena itu sumberdaya yang ada harus dilatih dan dipersiapkan secara matang agar mendukung program pemerintah di sektor pariwisata. Para sopir Gojek Online harus diberdayakan secara maksimal dari segi bahasa dan juga etika. Sangat penting bagi sopir Gojek Online untuk ber- Bahasa Inggris percakapan sehari-hari dan yang berhubungan dengan pekerjaan untuk meningkatkan pendapatan. Karena itu perlu dilaksanakan pelatihan Bahasa Inggris bagi para sopir Gojek Online, yang memberi jasa angkutan kepada wisatawan, mereka harus dibimbing melalui pelatihan bahasa sebagai alat komunikasi. Sebagai alat komunikasi, berarti para sopir haruslah diajari tentang struktur bahasa Inggris yang benar serta bagaimana bahasa Inggris itu digunakan dengan memperhatikan fakta - fakta di luar bahasa, situasi, dengan siapa berbicara, makna berbicara dan sebagainya.

Upaya yang dapat dilakukan adalah melalui pendidikan dan pelatihan. Menurut Tuloli (2001:99) bimbingan melalui pendidikan dan pelatihan pada dasarnya sangat penting sehingga salah satu bentuk investasi Sumber Daya Manusia salah satu kegiatan yang dapat diwujudkan adalah menyiapkan paket- paket pelatih yang mendukung penciptaan lapangan kerja, kreatifitas dan keterampilan.

Sumber daya yang ada di Kota Manado sudah saatnya harus dibimbing melalui pendidikan dan pelatihan, agar mereka mampu menjawab tantangan dibidang kepariwisataan. Khususnya sopir Gojek Online mereka harus dibimbing melalui pelatihan bahasa sebagai alat komunikasi. Sebagai alat komunikasi, berarti para sopir Gojek Online tidak hanya diajari tentang struktur bahasa Inggris yang benar akan tetapi bagaimana bahasa Inggris itu digunakan dengan memperhatikan fakta - fakta luar bahasa, situasi, dengan siapa berbicara, makna berbicara dan sebagainya.

\section{Permasalahan Mitra}

Di Indonesia Bahasa Inggris berkedudukan sebagai bahasa Asing. Bahasa inggris telah diajarkan di sekolah - sekolah pada tingkat Sekolah Menengah Pertama (SMP) dan Sekolah Menengah Atas (SMA), bahkan perguruan tinggi. Program studi ini telah banyak mencetak lulusan lulusan yang berkompeten dalam berbahasa inggris. Yang sangat ironis adalah megahnya bangunan, indahnya kehidupan di bawah laut dengan flora dan fauna yang khas dan bervariasi itu tidak dibarengi dengan peningkatan kualitas SDM sebagai pelaku industri jasa pariwisata. Para sopir Gojek Online belum diberdayakan untuk menjadi pelaku jasa pariwisata tersebut. Pada umumnya mereka tidak dapat berkomunikasi dengan bahasa asing terutama bahasa inggris, karena mereka pikir hanya bekerja sebagai sopir tidak memerlukan kemampuan berbahasa asing ataupun bahasa inggris. Ada banyak sopir Gojek Online yang hanya tamatan SMP bahkan ada yang hanya sampai SD jadi bahasa inggris mereka sangat minim, Pemerintah hendaklah proaktif membina para sopir Gojek Online menjadi SDM yang berkualitas baik secara fisik maupun non fisik.

Menurut Tuloli (2001:1994) untuk meningkatkan kualitas fisik pembinaan diarahkan ke program bidang kesehatan, olahraga dan gizi. Sedangkan peningkatan non fisik lebih banyak menyangkut program pendidikan, pelatihan, keterampilan, serta mental dan kejiwaan manusia. 
Selain masalah dari Para sopir Gojek Online yang masih minim penguasaan bahasa inggrisnya, masalah pengembangan bahasa inggris juga dirasakan masih kurang. Para sopir Gojek Online dapatlah menjadi sebagai pelaku jasa industri pariwisata belum memiliki buku penuntun percakapan dalam bahasa inggris. Jelaslah, pembinaan dan pengembangan bahasa inggris harus seiring dan sejalan agar hasil yang dicapai menjadi maksimal.

Bertolak dari kondisi yang telah digambarkan di atas, permasalahan mitra dapat difokuskan:

1. Para Sopir Gojek Online Manado belum mampu menggunakan bahasa inggris. Baik dari segi pengucapan, pelafalan maupun

2. Penguasaan kosa kata masih minim

3. Kurang memahami latar belakang sosial budaya para wisatawan.

4. Tidak memiliki referensi (buku - buku) berkaitan dengan percakapan sehari - hari meskipun di toko - toko buku telah di jual berbagai referensi percakapan dari bahasa inggris.

Bertolak dari permasalahan diatas perlu dilakukan tindakan agar Sopir Gojek Online Manado dapat memiliki pengetahuan dasar tentang bahasa Inggris yang dapat digunakannya untuk berkomunikasi dengan wisatawan. Tindakan ini dilakukan oleh pihak yang berkompetensi dalam hal ini perguruan tinggi sebagai pelaksana IPTEKS bagi Masyarakat (IbM). Kami dari Universitas Negeri Manado melaksanakan pengabdian merupakan IPTEKS bagi Masyarakat khususnya para Sopir Gojek Online Manado agar mereka dapat meningkatkan kemampuan berbahasa Inggris dengan baik dalam rangka menyukseskan program pemerintah.

\section{METODE}

Metode yang digunakan dalam pelatihan ini

1. Metode ceramah

Metode ini digunakan untuk menjelaskan materi tentang struktur bahasa Inggris, pelafalan diksi dan materi lainnya yang telah dituangkan dalam modul

2. Metode Diskusi dan Simulasi

Metode ini digunakan untuk mendiskusikan tentang yang diberikan oleh pelatih yaitu (1) menyusun dialog dalam bahasa Inggris, masing-masing kelompok dengan topik yang berbeda - beda. Dialog atau Conversation ini akan disimulasikan didepan kelas (2) mengerjakan teks bacaan yang baris - barisnya telah dikosongkan ( Emply outline) Sopir
Gojek Online diminta melengkapi teks tersebut

3. Metode pendampingan

Pelatih akan mendampingi kelompok selama mereka menyelesaikan tugas kelompok.

Syarat - syarat peserta pelatihan adalah:

1. Dapat membaca dan menulis

2. Memiliki kemampuan berbahasa Inggris tingkat dasar

3. Dapat diajar bekerja sama

4. Memiliki karakter sopan, menghargai orang lain, rendah hati dan ramah

5. Suka belajar

6. Memiliki alat ucap yang lengkap

7. Sedikitnya memiliki wawasan tentang Kota Manado

\section{Tahap Pelaksanaan}

Tahap pelaksana pelatihan melalui penahapan sebagai berikut :

1. Prapelatihan

a. Instruktur memberi salam, berdoa, mengecek kehadiran apakah sesuai dengan daftar

b. Menginformasikan tujuan yang akan dicapai melalui pelatihan yang akan digelar

c. Memberi motivasi tentang pentingnya para pemandu wisatawan menguasai bahasa Inggris

d. Menginformasikan tentang langkah langkah pelatihan bahasa Inggris yang akan digelar

2. Pelatihan

a. Instruktur membagi kelompok .

b. Instruktur membagikan modul. Masingmasing kelompok mengerjakan modul tersebut.

Modul revisi :

- Introduction

- Greeting

- Dealing with numbers (address, time, date)

- Giving direction

- Asking for information

- Cross culture understanding

c. Instruktur membagikan tugas untuk dikerjakan oleh Sopir Gojek Online pendampingan oleh instruktur

d. Setelah itu instruktur meminta setiap kelompok untuk menyelesaikan tugas (1) menyusun dialog sesuai dengan lokasi/objek wisata di Kota Manado dan tempat lainnya (2) melengkapi teks

e. Instruktur memanggil satu kelompok untuk mempresentasikan hasil kelompoknya, dan 
kelompok lain memberi tanggapan. Demikian seterusnya, sesama kelompok mendapatkan tugas yang sama

f. Instruktur dan sopir Gojek Online mengumpulkan tugas yang telah dikerjakan oleh mereka.

\section{HASIL DAN PEMBAHASAN}

Selama kegiatan pengabdian pada masyarakat ini berlangsung terlihat betapa besar apresiasi para peserta pelatihan. Hal ini terbukti dengan kehadiran dan partisipasi para Sopir Gojek Online Manado sepanjang pelatihan berlangsung, para Sopir Gojek Online Manado menyadari benar pentingnya pelatihan bahasa Inggris untuk mereka, terutama dalam menghadapi para wisatawan asing yang berkunjung ke Tomohon dan dalam memasarkan bunga-bunga mereka pada orang asing. Dan dengan pelatihan ini mereka mendapat pengetahuan serta bekal dalam meningkatkan kemampuan berkomunikasi dalam bahasa Inggris.

Materi atau topik yang diberikan dalam pelatihan ini meliputi bahan peningkatan tentang kebahasaan dan ketrampilan dalam berbahasa Inggris. Mengingat kegiatan pelatihan bertujuan untuk meningkatkan pengetahuan dan ketrampilan berbahasa Inggris.

Materi atau topik pelatihan ini menampilkan contoh-contoh penggunaan katakata, frase-frase dan kalimat-kalimat yang sering digunakan dalam keseharian kegiatan daripada florist. Diberikan pula situasi-situasi yang tepat dimana kata-kata, frase-frase dan kalimat-kalimat itu digunakan. Penyajian contoh-contoh situasi tersebut adalah penting supaya para pengguna bahasa dapat memahami dan mampu membedakan ungkapan untuk situasi formal maupun non formal. Lebi dari itu, faktor budaya juga dikemukakan dalam penggunaan ungkapan- ungkapan yang disajikan.

Materi yang diberikan meliputi:

1. Introduction

Ungkapan-ungkapan yang digunakan untuk memperkenalkan diri ataupun memperkenalkan orang lain.

2. Greeting

Ungkapan yang digunakan untuk memberi salam dan merespon, bila bertemu dengan orang lain.

3. Dealing with Numbers

Ungkapan yang berhubungan dengan angka atau bilangan, harga, nomor telephone dan alamat.
4. Giving Direction

Ungkapan yang digunakan dalam menanyakan serta memberitahukan atau menunjukan tempat/alamat.

5. Asking for information

Dalam kegiatan ini semua materi atau topik yang diberikan, digandakan untuk mempermudah dan mempetlancar kegiatan pelatihan ini sehingga pencapaian hasil menjadi maksimal sesuai yang diinginkan,

\section{KESIMPULAN}

Pelaksanaan kegiatan pelatihan bahasa Inggris bagi para Sopir Gojek Online Manado telah memberikan manfaat yang besar bagi setiap peserta. Melalui pelatihan ini para peserta telah memiliki cukup kosakata dalam bahasa Inggris sehingga mereka telah dapat berkomunikasi dalam bahasa Inggris untuk kegiatan-kegiatan setiap hari, seperti menyapa seseorang, menawarkan produknya serta mengetahui sebagian budaya, sopan santun dalam melayani tamu mancanegara.

\section{DAFTAR PUSTAKA}

Cahyono, Bambang Y. The Teaching of English Language Skills and English Language Components, Malang: State University of Malang Press.2010

Ferrer-Hanreddy, Jami \& Whalley, Elizabeth. A Listening/Speaking Skills Book: With Learning Strategies and Language Functions, Singapore: McGraw-Hill Companies, Inc. 1996

Silberman, Mel. Active Learning: 101 Strategi Pembelajaran Aktif, Yogyakarta: Pustaka Insan Madani. 2009.

Tillit Bruce \& Bruder Mary N. Speaking Naturally - Communication Skills In American English, Cambridge : Cambrige University Press. 